\title{
Synthesis, Characterization and Biological Studies of Adducts of Nickel(II)thioxanthates with Substituted Pyridines
}

\author{
POOJA SHARMA*, GURPREET KOUR, NEERUPAMA and RENU SACHAR
}

Department of Chemistry, University of Jammu, Babasaheb Ambedkar Road, Jammu-180006, India

1285pooja@gmail.com

Received 10 July 2014 / Accepted 26 July 2014

\begin{abstract}
Five new adducts of nickel(II)thioxanthates with substituted pyridines like ethylpyridines and chloropyridines have been synthesized. Structural features of adducts isolated in the solid state were established by several techniques using elemental analysis, molar conductance, magnetic susceptibility measurements, TGA-DTA and spectroscopic studies which include FTIR, UV-Vis and mass. These studies suggest that adducts have the general formula $\left[\mathrm{Ni}\left(\mathrm{S}_{2} \mathrm{CSC}_{3} \mathrm{H}_{7}\right)_{2} \mathrm{~L}_{2}\right]$ in which $\mathrm{L}=$ chloropyridines and ethylpyridines. Antifungal activities of these adducts have been carried out against the fungal strain Sclerotium rolfsii. Various studies support the distorted octahedral geometry around $\mathrm{Ni}(\mathrm{II})$ ion.
\end{abstract}

Keywords: Nickel(II)thioxanthates, Ethylpyridines, Chloropyridines, Sclerotium rolfsii

\section{Introduction}

1,1-Dithiolates form an interesting family of sulfur donor ligands. They have been extensively used in classical and organometallic chemistry for several years ${ }^{1-3}$. Among these much work has been done on alkyl dithiacarbamates, dithiocarboxylates, dithiocarbonates but little attention has been paid to alkyl trithiocarbonates ${ }^{4-10}$. Trithiocarbonates are used as antioxidant additives to lubricate oil and greases ${ }^{11}$, against human tumour ${ }^{12}$. Trithiocarbonate complexes have received attention because of the dual nature of metal - $\mathrm{CS}_{3}$ moiety as an electrophilic and nucleophilic reagents, which makes them versatile intermediates for the synthesis of other oil thio species. Although the main application is the treatment of a variety of rheumatic diseases, some of these compounds have shown to have antileshmanial activity in vitro inhibitory effect on HIV or activity tumor cell ${ }^{13-14}$. Organotrithiocarbonates have found many applications in various fields such as in analysis, organic synthesis, medicine, industry and agriculture some of these applications are as flotation agents, vulcanization accelerators, pesticides, plant defoliants, rust inhibitor, lubricant oil additives, and some have recently reported to possess activity as antiradiation drugs $^{15-16}$. S-alkyltrithiocarbonates commonly known as thioxanthates coordinate with a number of transition metals to form stable complexes. Here in this paper we report how the metal centre in these complexes coordinate with substituted pyridines to form adducts. 


\section{Experimental}

The elemental analysis was performed on elemental analyzer (Elemental vario EL III, carlo Erba 1108). Molar conductance was measured in DMF using CC 601 Conductivity Bridge. The IR spectra was recorded on a Infrared spectrophotometer (Perkin Elmer FTIR) over the region $4000-300 \mathrm{~cm}^{-1}$ using $\mathrm{KBr}$ pellets. The electronic absorption spectra were recorded on Systronic $119 \mathrm{UV}$-Vis spectrophotometer. The magnetic susceptibility was measured at room temperature by Guoy's method us ing $\mathrm{Hg}\left[\mathrm{Co}(\mathrm{CNS})_{4}\right]$ as calibrant. Thermo gravimetric analysis (TGA) of the present complex was determined on Linseis STA-PT- 1000 at $10{ }^{\circ} \mathrm{C} / \mathrm{min}$.

\section{Synthesis of sodium salt of isopropylthioxanthate ligand $\left[\mathrm{NaS}_{2} \mathrm{CSC}_{3} \mathrm{H}_{7}\right]$}

The sodium salt of isopropylthioxanthate was prepared (as reported in literature) ${ }^{17}$ by the drop wise addition of the isopropyl mercaptan $(1 \mathrm{~mol})$ to a saturated solution of sodium hydroxide at $0{ }^{\circ} \mathrm{C}$, followed by the addition of excess carbon disulfide $(1.2 \mathrm{~mol})$. The yellow precipitate formed immediately was collected by filteration and twice recrystallized from water-acetone mixture. The salt was characterized by its unpleasant odour and was stored in vacuum desiccators over phosphorus pentoxide.

$$
\mathrm{RSH}+\mathrm{CS}_{2}+\mathrm{NaOH} \stackrel{\mathrm{O}^{\circ} \mathrm{C}}{\longrightarrow} \mathrm{RSCS}_{2}^{-} \mathrm{Na}^{+}+\mathrm{H}_{2} \mathrm{O}
$$

Where $\mathrm{R}$ = isopropyl

\section{Synthesis of complex bis(isopropylthioxanthato)nickel(II)}

To sodium salt of isopropylthioxanthate $(0.02 \mathrm{~mol})$ an aqueous solution of $\mathrm{NiCl}_{2} .6 \mathrm{H}_{2} \mathrm{O}(0.01$ mol) was added. The mixture was immediately extracted with several portions of ether and the combined extracts were dried over anhydrous magnesium sulfate. The ether was removed under reduced pressure and shiny black crystals were isolated. The composition of the complex was established to be $\left[\mathrm{Ni}\left(\mathrm{S}_{2} \mathrm{CSC}_{3} \mathrm{H}_{7}\right)_{2}\right]$ by the elemental analysis.

$$
\mathrm{NiCl}_{2} \cdot 6 \mathrm{H} 2 \mathrm{O}+\mathrm{RSCS}_{2} \mathrm{Na} \longrightarrow\left[\mathrm{Ni}\left(\mathrm{RSCS}_{2}\right)_{2}\right]+\mathrm{NaCl}
$$

Synthesis of adducts of bis(isopropylthioxanthato)nickel(II) with substituted pyridines

Bis(isopropylthioxanthato)nickel(II) $(0.0026 \mathrm{~mol})$ was dissolved in acetone $(60-80 \mathrm{~mL})$ and stirred for about 10-20 minutes. To the resulting solution, substituted pyridines (where substituted pyridines $=$ ethylpyridines and chloropyridines $)(0.0052 \mathrm{~mol})$ was added. The mixture was stirred for two to three days and kept overnight. Green coloured precipitates were formed. The product so obtained was filtered and dried in vacuum desiccator over anhydrous calcium chloride. The composition of the adduct was established to be $\mathrm{Ni}\left[\left(\mathrm{S}_{2} \mathrm{CSC}_{3} \mathrm{H}_{7}\right)_{2} \mathrm{~L}_{2}\right]$.

$$
\left[\mathrm{Ni}\left(\mathrm{RSCS}_{2}\right)_{2}\right]+\mathrm{L} \longrightarrow\left[\mathrm{Ni}\left(\mathrm{RSCS}_{2}\right)_{2}(\mathrm{~L})_{2}\right]
$$

Where $\mathrm{L}=$ ethylpyridines and chloropyridines

\section{Results and Discussion}

The adducts were analyzed by various analytical and physicochemical techniques and the results shows that bis(isopropylthioxanthato)nickel(II) forms 1:2 adducts with substituted pyridines (where substituted pyridines = ethylpyridines and chloropyridines). The analytical data (Table 1) reveals that 1:2 adduct have general formula $\mathrm{Ni}\left[\mathrm{S}_{2} \mathrm{CS}\left(\mathrm{C}_{3} \mathrm{H}_{7}\right)\right]_{2} \mathrm{~L}_{2}(\mathrm{~L}=$ ethylpyridines and chloropyridines). All the adducts are coloured and stable in air. 
Conductance measurements were done to ascertain the electrolytic/ non-electrolytic nature of the metal complexes. The molar conductivity values of $1: 2$ adducts of $\mathrm{Ni}\left[\mathrm{S}_{2} \mathrm{CS}\left(\mathrm{C}_{3} \mathrm{H}_{7}\right)\right]_{2} \mathrm{~L}_{2}$ measured in $10^{-3} \mathrm{M}$ DMF solution are found to be in the range of $59.67-59.73 \mathrm{ohm}^{-1} \mathrm{~cm}^{2} \mathrm{~mol}^{-1}$ (Table 2). These values supports the neutral and non-ionic nature of the complexes ${ }^{18-19}$.

\section{Magnetic susceptibility measurement}

The 1:2 adducts of bis(isopropylthioxanthato)nickel(II) with ethylpyridines and chloropyridines exhibit magnetic moment values in the range of 3.19-3.23 B.M (Table 2) which is in agreement with magnetic moment values observed for paramagnetic octahedral complexes of nickel(II) $)^{20}$.

Table 1. Analytical data of $1: 2$ adducts of bis(isopropylthioxanthato)nickel(II) with substituted pyridines

\begin{tabular}{lccccccccccc}
\hline & \multicolumn{1}{c}{ \% Found } & \multicolumn{6}{c}{ \% Calculated } \\
\cline { 2 - 9 } S.No & Name of the adduct & $\mathrm{C}$ & $\mathrm{H}$ & $\mathrm{N}$ & $\mathrm{S}$ & $\mathrm{C}$ & $\mathrm{H}$ & $\mathrm{N}$ & $\mathrm{S}$ \\
\hline 1 & $\begin{array}{c}\text { Bis(isopropylthioxanthato)bis } \\
\text { (2-ethylpyridine)nickel(II) }\end{array}$ & 45.18 & 5.02 & 4.18 & 32.93 & 45.94 & 5.57 & 4.87 & 33.41 \\
2 & $\begin{array}{c}\text { Bis(isopropylthioxanthato)bis } \\
\text { (3-ethylpyridine)nickel(II) }\end{array}$ & 45.34 & 4.98 & 4.23 & 32.87 & 45.94 & 5.57 & 4.87 & 33.41 \\
3 & $\begin{array}{c}\text { Bis(isopropylthioxanthato)bis } \\
\text { (4-ethylpyridine)nickel(II) }\end{array}$ & 45.26 & 5.08 & 4.27 & 32.82 & 45.94 & 5.57 & 4.87 & 33.41 \\
4 & $\begin{array}{c}\text { Bis(isopropylthioxanthato)bis } \\
\text { (2-chloropyridine)nickel(II) }\end{array}$ & 36.13 & 3.33 & 4.16 & 32.16 & 36.76 & 3.74 & 4.77 & 32.68 \\
5 & $\begin{array}{c}\text { Bis(isopropylthioxanthato)bis } \\
\text { (3-chloropyridine)nickel(II) }\end{array}$ & 36.19 & 3.13 & 4.23 & 32.29 & 36.76 & 3.74 & 4.77 & 32.68 \\
\hline
\end{tabular}

Table 2. Colour, molar conductance and magnetic moments of $1: 2$ adducts of bis(isopropylthioxanthato)nickel(II) with substituted pyridines

\begin{tabular}{clccc}
\hline S.No. & \multicolumn{1}{c}{ Name of the adduct } & Colour & $\begin{array}{c}\text { Molar } \\
\text { conductance, } \\
\mathrm{ohm}^{-1} \mathrm{~mol}^{-1} \mathrm{~cm}^{2}\end{array}$ & $\begin{array}{c}\mu_{\text {eff }} \text { (B.M.) } \\
\text { at 293K }\end{array}$ \\
\hline 1 & $\begin{array}{l}\text { Bis(isopropylthioxanthato)bis(2- } \\
\text { ethylpyridine)nickel(II) }\end{array}$ & Green & 59.69 & 3.20 \\
2 & $\begin{array}{l}\text { Bis(isopropylthioxanthato)bis(3- } \\
\text { ethylpyridine)nickel(II) }\end{array}$ & Green & 59.71 & 3.23 \\
3 & $\begin{array}{l}\text { Bis(isopropylthioxanthato)bis(4- } \\
\text { ethylpyridine)nickel(II) }\end{array}$ & Green & 59.68 & 3.21 \\
4 & $\begin{array}{l}\text { Bis(isopropylthioxanthato)bis(2- } \\
\text { chloropyridine)nickel(II) }\end{array}$ & Green & 59.73 & 3.19 \\
\hline & $\begin{array}{l}\text { Bis(isopropylthioxanthato)bis(3- } \\
\text { chloropyridine)nickel(II) }\end{array}$ & Green & 59.67 & 3.20 \\
\hline
\end{tabular}

\section{IR spectra}

The IR spectra of the free ligand and the complexes were obtained in the range of 4000-300 $\mathrm{cm}^{-1}$. All the bands present in the IR spectra of the free ligand were also observed in the spectra of the complexes. In the present work IR spectra of the adducts of bis(isopropylthioxanthato)nickel(II) with substituted pyridines show characteristic bands corresponding to $v(\mathrm{C}-\mathrm{S}-\mathrm{C})_{\text {asym }}$ and 
$v(\mathrm{C}-\mathrm{S}-\mathrm{C})_{\mathrm{sym}}$ vibrations in the range of 693-703 and 655-659 $\mathrm{cm}^{-1}$. An intense band corresponding to $v(\mathrm{C}-\mathrm{S})$ vibration is also observed in the range of $1035-1043 \mathrm{~cm}^{-1}$ for the adducts synthesized which suggests that thioxanthate is binding as symmetrical bidentate chelating ligand (Table 3). On formation of adducts, there is a shift in the stretching frequencies, because of donation of electrons by the Lewis bases which weakens the metal sulfur bond that leads to corresponding weakening of $\mathrm{C}-\mathrm{S}$ bond ${ }^{21-22}$. A band of medium to strong intensity observed in the region $391-395 \mathrm{~cm}^{-1}$ may be assigned due to (Ni-S) stretching mode $\mathrm{e}^{23}$.

\section{UV-Visible spectra}

The electronic spectra of adducts of nickel(II)thioxanthates show three absorption bands in the range of 13293-13306 $\mathrm{cm}^{-1}, 19781-19789 \mathrm{~cm}^{-1}$ and 24589-24596 $\mathrm{cm}^{-1}$ (Table 3). These three bands may be assigned to three spin allowed transitions ${ }^{3} \mathrm{~A}_{2} \mathrm{~g} \rightarrow{ }^{3} \mathrm{~T}_{2} \mathrm{~g}(\mathrm{~F})\left(v^{1}\right)$, ${ }^{3} \mathrm{~A}_{2} \mathrm{~g} \rightarrow{ }^{3} \mathrm{~T}_{1} \mathrm{~g}(\mathrm{~F})\left(v^{2}\right)$ and ${ }^{3} \mathrm{~A}_{2} \mathrm{~g} \rightarrow{ }^{-3} \mathrm{~T}_{1} \mathrm{~g}(\mathrm{P})\left(v^{3}\right)$ respectively. The appearance of these bands along with shoulders suggest that the adducts synthesized have distorted octahedral geometry around $\mathrm{Ni}(\mathrm{II})$ metal ion $^{24}$.

Table 3. Electronic and vibrational spectral data of 1:2 adducts of bis(isopropylthioxanthato)nickel(II) with substituted pyridines

\begin{tabular}{|c|c|c|c|c|c|c|}
\hline \multirow[t]{2}{*}{$\begin{array}{l}\stackrel{\circ}{Z} \\
\dot{\infty}\end{array}$} & \multirow[t]{2}{*}{ Name of the adduct } & $\begin{array}{l}\text { Electronic spectral } \\
\text { data in } \mathrm{cm}^{-1}\end{array}$ & $\begin{array}{l}\text { ectral } \\
\mathrm{h}^{-1}\end{array}$ & \multicolumn{3}{|c|}{$\begin{array}{l}\text { Vibrational spectral data in } \\
\qquad \mathrm{cm}^{-1}\end{array}$} \\
\hline & & $v_{2}$ & $v \mathrm{C}-\mathrm{S}$ & $(\mathrm{C}-\mathrm{S}-\mathrm{C}$ & As $v(C-S-C$ & $\mathrm{S}_{\mathrm{S}}(\mathrm{Ni}-\mathrm{S})$ \\
\hline 1 & $\begin{array}{l}\text { Bis(isopropylthioxanthato)bis } \\
\text { (2-ethylpyridine)nickel(II) }\end{array}$ & 1330619789 & 245961035 & 693 & 655 & 391 \\
\hline 2 & $\begin{array}{l}\text { Bis(isopropylthioxanthato)bis } \\
\text { (3-ethylpyridine)nickel(II) }\end{array}$ & 19782 & 040 & 699 & 657 & 394 \\
\hline 3 & $\begin{array}{l}\text { Bis(isopropylthioxanthato)bis } \\
\text { (4-ethylpyridine)nickel(II) }\end{array}$ & 1329719787 & 1037 & 697 & 656 & 393 \\
\hline 4 & $\begin{array}{l}\text { Bis(isopropylthioxanthato)bis } \\
\text { (2-chloropyridine)nickel(II) }\end{array}$ & 1329719781 & 245891043 & 703 & 659 & 395 \\
\hline 5 & $\begin{array}{l}\text { Bis(isopropylthioxanthato)bis } \\
\text { (3-chloropyridine)nickel(II) }\end{array}$ & $132981978^{\prime}$ & 245931039 & 698 & 656 & 393 \\
\hline
\end{tabular}

\section{Thermal studies}

The adducts were subjected to TG analysis from $25{ }^{\circ} \mathrm{C}$ to $1000{ }^{\circ} \mathrm{C}$ in nitrogen atmosphere and the results of the novel investigated adducts is as given below. The TG curve of the adduct show a continuous weight loss and a stable sulfide, NiS, was formed as an end product. An initial weight loss of $35.14 \%$ was observed at around $350{ }^{\circ} \mathrm{C}$ due to the loss of two ethylpyridine molecules (calculated weight loss $=37.23 \%$ ). Then a continuous weight loss of $83.7 \%$ was observed, which may be due to the loss of $\mathrm{C}_{22} \mathrm{H}_{32} \mathrm{~N}_{2} \mathrm{~S}_{5}$ moiety (calculated weight loss $=84.22 \%$ ), till a stable sulfide NiS is formed ${ }^{25}$ (Figure 1).

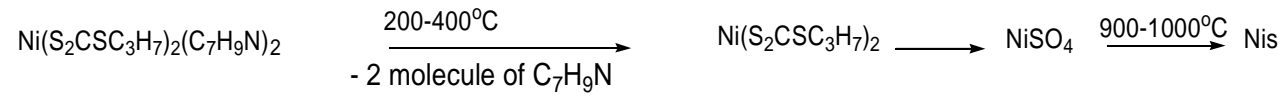

\section{Mass spectroscopy}

Mass spectroscopy is one of the most important methods to determine molecular weight of the complexes and to identify the fragments formed during bombardment, which reveal composition and properties of the particular moiety of the complexes. Mass spectra of one of these adducts, bis(isopropylthioxanthato)bis(3-ethylpyridine)nickel(II) has been recorded. The possible formulae of the fragments and their $\mathrm{m} / \mathrm{z}$ ratios are shown in Table 4 . 


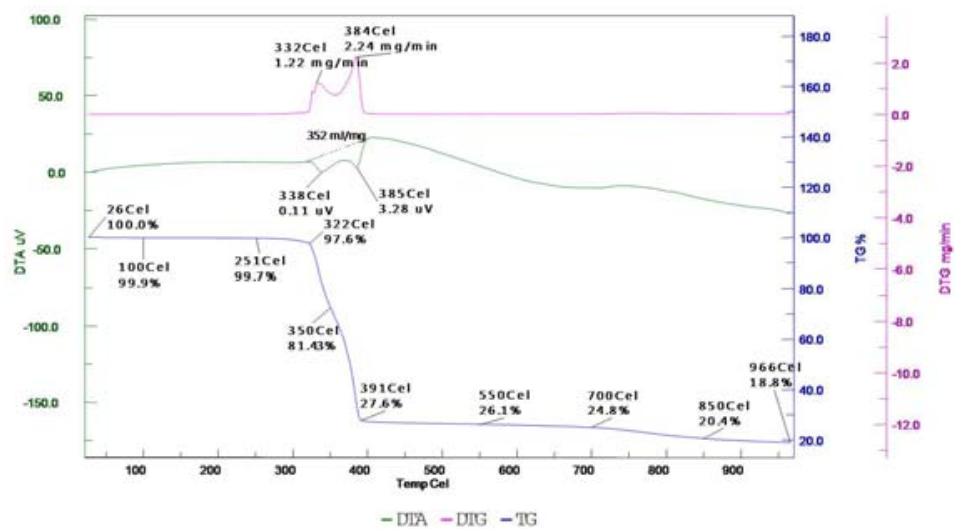

Figure 1. TGA-DTA curve of bis(isopropylthioxanthato)bis(4-ethylpyridine) nickel(II)

Table 4. Mass fragments of bis(isopropylthioxanthato)bis(3-ethylpyridine) nickel(II)

\begin{tabular}{cc}
\hline Mass $m / z$ & possible formulae of the fragment \\
\hline 574 & $\mathrm{Ni}\left[\left(\mathrm{S}_{2} \mathrm{CSC}_{3} \mathrm{H}_{7}\right)_{2}\left(\mathrm{C}_{7} \mathrm{H}_{9} \mathrm{~N}\right)_{2}\right]^{+}$. \\
360 & $\mathrm{Ni}\left[\left(\mathrm{S}_{2} \mathrm{CSC}_{3} \mathrm{H}_{7}\right)_{2}\right]^{+}$. \\
208 & $\mathrm{Ni}\left[\left(\mathrm{S}_{2} \mathrm{CSC}_{3} \mathrm{H}_{7}\right)\right]^{+}$. \\
146 & {$\left[\left(\mathrm{~S}_{2} \mathrm{CSC}_{3} \mathrm{H}_{7}\right)\right]^{+}$.} \\
108 & {$\left[\left(\mathrm{~S}_{2} \mathrm{CS}\right]^{+}\right.$.} \\
75 & {$\left[\mathrm{~S}_{2} \mathrm{C}\right]^{+}$.} \\
\hline
\end{tabular}

Two important peaks were observed in the mass spectrum: the molecular ion peak, indicating the molecular mass of the complex, which is very weak in case of the complexes investigated and the base peak, corresponding to the fragment $\mathrm{Ni}\left[\left(\mathrm{S}_{2} \mathrm{CSC}_{3} \mathrm{H}_{7}\right)_{2}\right]^{+}$. This indicates, in both cases, the strong chelating property of thioxanthates. The various fragments observed are in agreement with the molecular formula of the complexes ${ }^{26-27}$.

\section{Biological studies}

The antifungal activity of the complex was tested by Poisoned Food Technique against the pathogenic fungus, Sclerotium rolfsii. The linear growth of fungus in controlled manner was recorded at different concentrations of the complexes. The growth inhibition of fungus over control was calculated (Table 5) and it shows that on increasing the concentration of the complexes, the colony diameter of the fungus decreases and hence percent inhibition increases (Figure 2). The growth inhibition of Sclerotium rolfsii over control was calculated as:

$$
\% \text { Inhibition }(\mathrm{I})=\mathrm{C}-\mathrm{T} / \mathrm{C} \times 100
$$

Table 5. Antifungal activities of some adducts mean colony diameter in the control $=94 \mathrm{~mm}$

\begin{tabular}{|c|c|c|c|c|}
\hline $\begin{array}{l}\dot{0} \\
\dot{Z}\end{array}$ & Name of the adduct & $\begin{array}{l}\text { Concentration, } \\
\text { ppm }\end{array}$ & $\begin{array}{c}\text { Colony } \\
\text { diameter, } \mathrm{mm}\end{array}$ & $\begin{array}{l}\% \text { Inhibition }(\mathrm{I}) \\
=[(\mathrm{C}-\mathrm{T}) / \mathrm{C}] \times 100\end{array}$ \\
\hline \multirow{4}{*}{1} & \multirow{4}{*}{$\begin{array}{l}\text { Bis(isopropylthioxanthato)bis } \\
\text { (3-ethylpyridine)nickel(II) }\end{array}$} & 100 & 93 & 1.06 \\
\hline & & 200 & 83 & 11.70 \\
\hline & & 400 & 35 & 62.77 \\
\hline & & 800 & 8 & 91.49 \\
\hline \multirow{4}{*}{2} & \multirow{4}{*}{$\begin{array}{l}\text { Bis(isopropylthioxanthato)bis } \\
\text { (2-chloropyridine)nickel(II) }\end{array}$} & 100 & 95 & 1.06 \\
\hline & & 200 & 88 & 6.38 \\
\hline & & 400 & 37 & 60.64 \\
\hline & & 800 & 7 & 92.55 \\
\hline
\end{tabular}




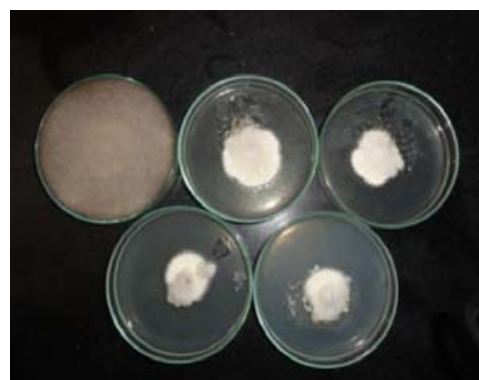

(a)

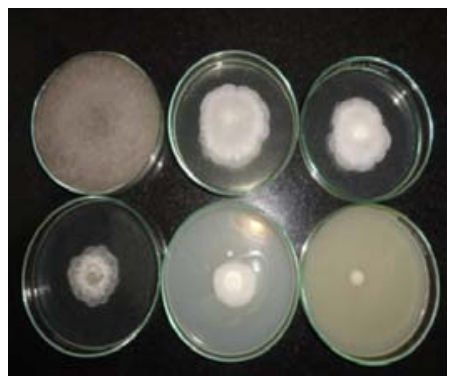

(a)

Figure 2. Antifungal activity of the adducts of (a) Bis(isopropylthioxanthato)bis(3ethylpyridine)nickel(II) and (b) Bis(isopropylthioxanthato)bis(2-chloropyridine)nickel(II)

Where $\mathrm{I}=$ percent inhibition, $\mathrm{C}=$ mean growth of fungus(in $\mathrm{mm}$ ) in control and $\mathrm{T}=$ mean growth of fungus (in $\mathrm{mm}$ ) in treatment.

\section{Conclusion}

On the basis of above studies it is found that 1:2 adducts of bis(isopropylthioxanthato)nickel(II) with ethylpyridines and chloropyridines have distorted octahedral geometry.

\section{References}

1. Wasson J R, Woltermann G M and Stoklosa H J, Top Curr Chem., 1973, 35(3-4), 65.

2. Livingstone S E, in Comprehensive coordination chemistry (Eds.), Wilkinson G, Gillard R D and McCleverty J A, (Oxford: Pergamon Press), 1987, 2, 633-659.

3. Haiduc I, In Comprehensive Coordination Chemistry- II (Eds.), McCleverty J A and Meyer T J, (Elsevier) 2004, Vol 1, Chapter 1.15, 349-376.

4. San H Thang, Chong Y K, Roshan T, Mayadunne A, Graeme Moad and Ezio Rizzardo, Tetrahedr Lett., 1999, 40(12), 2435-2438;

DOI:10.1016/S0040-4039(99)00177-X

5. Pastorek R, Travnicek Z, Sindelar Z, Klicka R and Brezina F, Polyhedron, 1958, 14(12), 1615-1620; DOI:10.1016/0277-5387(94)00433-F

6. Ballester L, Gutierrez A, Perpinan M F and Caridad Ruiz-Valero, Polyhedron, 1996, 15(7), 1103-1112; DOI:10.1016/0277-5387(95)00358-4

7. Yin H D and Wang C H, Appl Organometal Chem., 2005, 19(3), 400; DOI:10.1002/aoc.859

8. Haiduc I, Semeniuc R F, Campian M, Ch. Kravtsov V, Simonov Y A and Lipkowski J, Polyhedron. 2003, 22(21), 2895-2900; DOI:10.1016/S0277-5387(03)00399-1

9. Chouhan H P S, Bakshi A and Bhatia S. Phosphorus Sulfur Silicon, 2011, 186(2), 345-353; DOI:10.1080/10426507.2010.501320

10. Chaudhari K R, Wadawale A P, Jain V K, Yadav N and Bohra R, Indian J Chem., 2010, 49A, 34-38.

11. Vicente J, Chicote M T, Gonzalez-Herrero P and Jones P G, Inorg Chem., 1997, 36(25), 5735-5739; DOI:10.1021/ic970478c

12. Struck R F and Waud W R, Can Chemother Pharmacol. 2006, 57(2), 180-184; DOI:10.1007/s00280-005-0031-6

13. Vincete J, Chicote M, Gonzalez Herrero P and Jones P G, J Chem Soc Chem Commun., 1995, 7, 745-746; DOI:10.1039/C39950000745 
14. Dehmel F, Ciossek T, Maier T, Weinbrenner S, Scmidt B, Zoche M and Beckers T, 2007, 17(17), 4746-4752.

15. Srivastava A, Singh S K and Gupta A, Analyst, 1990, 115(4), 421-423; DOI:10.1039/AN9901500421

16. Ali M F and Abbas S, Fuel Process Technol., 2006, 87(7), 573-584; DOI:10.1016/j.fuproc.2006.03.001

17. Hyde J, Venkatasubramanian K and Zubieta J, Inorg Chem., 2007, 17(2), 414-426, 1978.

18. Martin R L and Whitley A. J Chem Soc., 1958, 1394-1402; DOI:10.1039/JR9580001394

19. Geary W J, Coord Chem Rev., 1971, 7(1), 81-122;

DOI:10.1016/S0010-8545(00)80009-0

20. Basolo F and Matousch W R. J Am Chem Soc., 1953, 75(22), 5663-5666; DOI:10.1021/ja01118a057

21. Carmona E, Contreras L, Sánchez L J, Puebla E G and Monge A, J Chem Soc., Dalton Trans., 1989, 2003-2009; DOI:10.1039/DT9890002003

22. Perpinan M F, Ballester L, González-Casso M E and Santos A, J Chem Soc., Dalton Trans., 1987, 281-284; DOI:10.1039/DT9870000281

23. Chen J, Huang Y, Liu G, Afrasiabi Z, Sinn E, Padhye S and Ma Y, Toxicol Appl Pharamacol., 2004, 197(1), 40-48; DOI:10.1016/j.taap.2004.02.004

24. Lee C M, Chiou T W, Chen H H, Chiang C Y, Kuo T S and Liaw W F. Inorg Chem., 2007, 46(21), 8913-8923; DOI:10.1021/ic700719h

25. Spek A L, Acta Cryst., 2009, D65(2), 148-155; DOI:10.1107/S090744490804362X

26. Silverstein R M, Bassler G C and Morrill T C, Spectrometric of Organic Compounds; $4^{\text {th }}$ Ed., Willey: New York, 1981, 3-15.

27. Kheiri F M N, Tsipis C A and Manoussakis G E, Inorg Chim Acta, 1977, 25, 223-227. DOI:10.1016/S0020-1693(00)95717-7

28. Parekh H M, Pansuriya P B and Patel M N, Polish J Chem., 2005, 79, 1843-1851. 